\title{
Experimental Investigation on Thermoelectric Chiller Driven by Solar Cell
}

\author{
Yen-Lin Chen, ${ }^{1}$ Zi-Jie Chien, ${ }^{2}$ Wen-Shing Lee, ${ }^{2}$ Ching-Song Jwo, ${ }^{2}$ and Kun-Ching Cho ${ }^{3}$ \\ ${ }^{1}$ Department of Computer Science and Information Engineering, National Taipei University of Technology, Taipei 10608, Taiwan \\ ${ }^{2}$ Department of Energy and Refrigerating Air-Conditioning Engineering, National Taipei University of Technology, \\ Taipei 10608, Taiwan \\ ${ }^{3}$ Department of Civil Engineering, Texas A\&M University, College Station, TX 77843-3136, USA
}

Correspondence should be addressed to Kun-Ching Cho; tedjwo@gmail.com

Received 11 April 2014; Accepted 15 May 2014; Published 16 June 2014

Academic Editor: Chao-Rong Chen

Copyright (C) 2014 Yen-Lin Chen et al. This is an open access article distributed under the Creative Commons Attribution License, which permits unrestricted use, distribution, and reproduction in any medium, provided the original work is properly cited.

\begin{abstract}
This paper presents experimental explorations on cooling performance of thermoelectric chillers being driven by solar cells, as well as comparison results to the performance being driven by fixed direct current. Solar energy is clear and limitless and can be collected by solar cells. We use solar cells to drive thermoelectric chillers, where the cold side is connected to the water tank. It is found that $250 \mathrm{~mL}$ of water can be cooled from $18.5^{\circ} \mathrm{C}$ to $13^{\circ} \mathrm{C}$, where the corresponding coefficient of performance (COP) is changed between 0.55 and 1.05 , when solar insolation is changed between $450 \mathrm{~W} / \mathrm{m}^{2}$ and $1000 \mathrm{~W} / \mathrm{m}^{2}$. The experimental results demonstrate that the thermoelectric chiller driven by solar cell is feasible and effective for energy saving issues.
\end{abstract}

\section{Introduction}

Renewable energy resources become important energy sources over the world. People apply more renewable energy sources and technologies so as we can reduce the consumption of traditional fossil energy. Therefore, the carbon dioxide production can be significantly reduced, and global warming problem can also be slowed down [1]. Solar chillers could be accomplished by using one of the following refrigeration systems: vapor compression, adsorption refrigeration [2], and thermoelectric refrigeration systems. The first two systems require low and high pressure sides of working fluids in refrigeration cycles and are difficult to be developed into portable and lightweight solar devices used in outdoor environments. The thermoelectric refrigeration system can provide advantages of being small, lightweight, reliable, noiseless, portable, and of low cost in mass production [3]. In our studies, solar cells are used to drive the thermoelectric chillers.

Gaur and Tiwari found that the energy efficiency of solar cell is about $10 \%$ to $25 \%$ [4]. Based on the calculations of the solar cell modules made in laboratory, cadmium telluride
(CdTe) has shown that it can provide the minimum cost per unit electrical energy, whereas amorphous silicon (a$\mathrm{Si}$ )/nanocrystalline silicon ( $\mathrm{nc}-\mathrm{Si}$ ) can provide the minimum cost for unit electrical energy when commercial availability of solar modules is concerned. Copper indium gallium diselenide (CIGS) can achieve the lowest capitalized cost over all other solar cell technologies. Yang and Yin have presented a hybrid solar system that utilizes photovoltaic cells, thermoelectric modules, and hot water [5]. The hybrid solar system is superior to traditional PV systems with $30 \%$ higher output electric power.

Peltier effect and Seebeck effect were first discovered to present in metals as early as 1820 s-1830s [6,7]. Despite their low energy efficiency as compared to traditional devices, thermoelectric effects present distinct advantages such as compactness, precision, simplicity, and reliability. Applications of thermoelectric devices are very wide in many areas, including equipment used in military, aerospace, medical, industrial, consumer, and scientific institutions [8]. Solardriven thermoelectric technologies have two types: the solardriven thermoelectric refrigeration and the solar-driven thermoelectric power generation [9]. One important application 


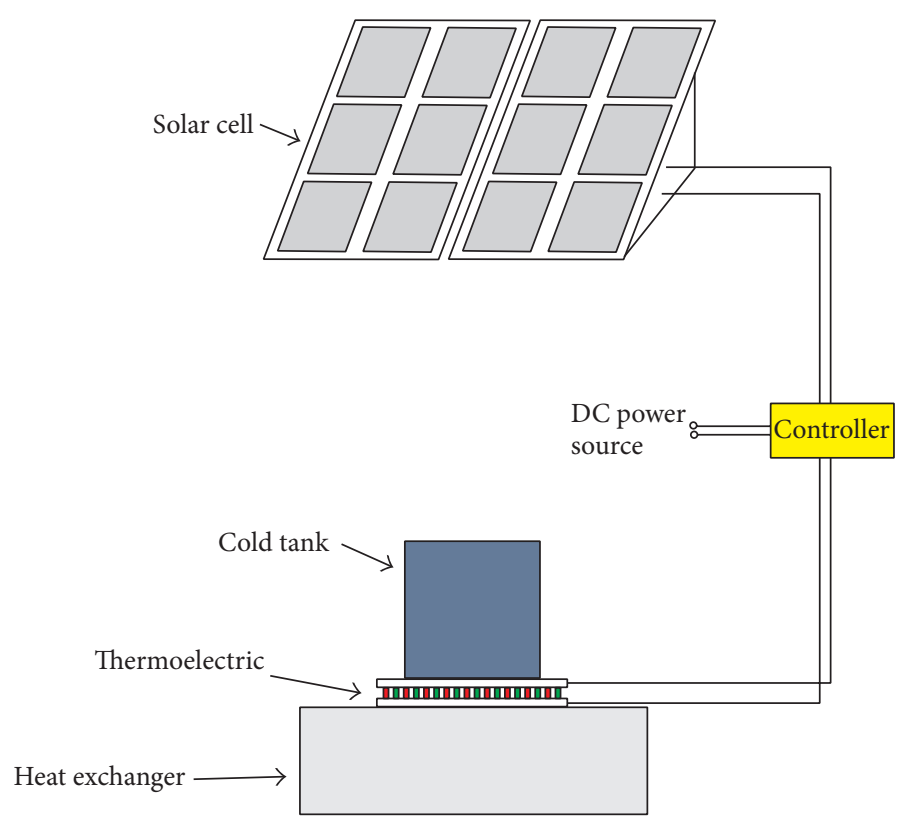

FIGURE 1: Solar thermoelectric chiller.

is thermoelectric generation with waste energy and renewable energy. Champier et al. incorporated wood stove with thermoelectric generator. In their system, the hot side of thermoelectric generator passes through hot air, whereas the cold side of thermoelectric generator is put under two liters of water tank. This system can produce up to $9.5 \mathrm{~W}$ as they used prototype of ten watts thermoelectric generator [10]. Meng et al. [11] presented a system that adopted the flushing water of blast furnace slag, and about $0.93 \mathrm{~kW}$ electrical energy can be produced per unit area when the temperature of flushing water starts at $100^{\circ} \mathrm{C}$ with a temperature drop of $1.5^{\circ} \mathrm{C}$ and the conversion efficiency is $2 \%$. The cost recovery period of the equipment is about 8 years. Attia et al. [12] have reported an experimental power generation device that can produce electrical energy in milliwatts level by using standard bismuth telluride thermoelectric modules with a device size of about $10 \mathrm{~cm}^{3}$. Rezania et al. [13] explored the effective pumping power for the cooling system at five temperature differences of the hot and cold sides of the thermoelectric generation device. Their experimental results demonstrated that there is a unique flow rate that gives maximum net power in the system at each temperature difference. Chávez Urbiola and Vorobiev [14] studied solar hybrid electric/thermal system using photovoltaic panels combined with a water/air-filled heat extracting unit and thermoelectric generators. Their experiment results showed that the hot side of thermoelectric generation at midday has a temperature of around $200^{\circ} \mathrm{C}$ and the cold side is approximately $50^{\circ} \mathrm{C}$. This system generated $20 \mathrm{~W}$ of electrical energy and $200 \mathrm{~W}$ of thermal energy.

Another important application of thermoelectric is for cooling operations [15]. Dai et al. [3] conducted experimental investigation on thermoelectric refrigerator driven by solar cells. The results demonstrated that the unit could maintain the temperature in the refrigerator at $5-10^{\circ} \mathrm{C}$ and have a COP about 0.3. He et al. [16] conduct experiments on thermoelectric cooling and heating system driven by solar power in a model room whose volume is $0.125 \mathrm{~m}^{3}$ and performed the test in summer time. The resulting COP of their proposed thermoelectric device is of average 0.6. Zhou and $\mathrm{Yu}$ [17] present a generalized theoretical model for the optimization of a thermoelectric cooling system. Their analysis showed that the maximal COP and the maximal cooling capacity can be obtained when the finite thermal conductance is optimally allocated. Abdul-Wahab et al. [18] designed and built an affordable solar thermoelectric refrigerator. Their results indicated that the temperature of the refrigeration was reduced from $27^{\circ} \mathrm{C}$ to $5^{\circ} \mathrm{C}$ in approximately 44 minutes. The COP of their system was calculated and found to be about 0.16. Chang et al. [19] investigated the thermoelectric air-cooling module for electronic devices. The results demonstrated that their thermoelectric air-cooling module can provide better performance at a low heat loading condition.

This study develops the thermoelectric chiller driven by solar cell in daytime and direct current (DC) source in cloudy days or nighttime. The solar thermoelectric chiller is investigated in terms of COP and the temperature of thermoelectric through a specially designed test rig.

\section{Configuration of the Solar Thermoelectric Chiller}

Figure 1 is the schematics thermoelectric chiller driven by solar cell. The chiller mainly consists of the one solar cell, thermoelectric, controller, and water tank. The specifications of the proposed solar thermoelectric chiller are shown in Table 1. One solar cell can be commercially available. Solar insolation is $1000 \mathrm{~W} / \mathrm{m}^{2}$; maximum of $P_{\text {solar }}$ is $130 \mathrm{~W}$. The maximum voltage of the solar cell is $17.6 \mathrm{~V}$, the maximum 
TABLE 1: Specifications of solar thermoelectric chiller.

\begin{tabular}{lclc}
\hline \multicolumn{2}{c}{ Solar cell } & \multicolumn{2}{c}{ Thermoelectric element } \\
At $S$ & $1000 \mathrm{~W} / \mathrm{m}^{2}$ & At $T_{H}$ & $25^{\circ} \mathrm{C}$ \\
\hline$P_{\text {solar,max }}$ & $130 \mathrm{~W}$ & $Q_{c, \text { max }}$ & $49 \mathrm{~W}$ \\
$V_{\text {solar,max }}$ & $17.6 \mathrm{~V}$ & $\Delta T_{\max }$ & $75^{\circ} \mathrm{C}$ \\
$I_{\text {solar,max }}$ & $7.39 \mathrm{~A}$ & $V_{\text {tec, } \max }$ & $16.2 \mathrm{~V}$ \\
$A$ & $0.89 \mathrm{~m}^{2}$ & $I_{\text {tec, } \max }$ & $5.3 \mathrm{~A}$ \\
$\eta_{P V}$ & $13 \%$ & $R_{\text {tec }}$ & $2.75 \Omega$ \\
& & $\alpha$ & $0.0508 \mathrm{~V} / \mathrm{K}$ \\
& & $K$ & $0.38 \mathrm{WK}^{-1}$ \\
& & $Z$ & $2.47 \times 10^{-3} 1 / \mathrm{K}$ \\
\hline
\end{tabular}

current of the solar cell is $7.39 \mathrm{~A}$, its area is $0.89 \mathrm{~m}^{2}$, and the corresponding energy efficiency of the solar cells $\eta_{P V}$ is $11 \%$. We adopt a commercially available thermoelectric device; its size is $40 \mathrm{~mm} \times 40 \mathrm{~mm} \times 4.2 \mathrm{~mm}$ and the corresponding specifications are TEC-127-05 with 127 couples of $p$ - $n$ bismuth tin (BiSn) alloy thermoelement sandwiched between two thin ceramic plates. At the hot side, the temperature is $50^{\circ} \mathrm{C}$. The maximal cooling production is $49 \mathrm{~W}$. The maximum temperature difference between the hot and cold sides is $75^{\circ} \mathrm{C}$. The maximum thermoelectric voltage is $16.2 \mathrm{~V}$, and the maximum thermoelectric current is $5.3 \mathrm{~A}$. The electrical resistance is $2.75 \Omega$. The function of the controller is switching power supply between solar cells and the DC power source. The water tank is filled with $250 \mathrm{~mL}$ of ambient temperature water.

The hot side of the thermoelectric system was connected to the heat exchanger to provide more cooling efficiency. The thermoelectric cooling process is performed when a fixed direct current is passed through one or more pairs of $n$-type to $p$-type junctions. As the differences of the current and temperature increase, Peltier cooling effect can be accordingly increased. However, main loss in Joule heat is also proportional to the square of the current and, therefore, eventually becomes the dominant factor. In the daytime, the thermoelectric chiller is driven by solar cells. In the nighttime, the thermoelectric chiller is driven by fixed direct current.

\section{Experimental Study}

3.1. Theory Consideration. Solar cell is used in driven thermoelectric chiller. The output electric power is calculated by the following equation [3]:

$$
P_{\text {solar }}=S A \eta_{P V}
$$

where $S$ is the solar insolation rate, $A$ is the area of the solar cell to receive solar irradiation, and $\eta_{P V}$ is the efficiency of energy conversion from solar energy to electric power.

The heat absorption rate at the cold side, that is, the cooling capacity, can be obtained by

$$
Q_{c}=\alpha I T_{c}-0.5 I^{2}-K\left(T_{h}-T_{c}\right) .
$$

The input voltage of the thermoelectric is given by

$$
V=\alpha\left(T_{h}-T_{c}\right)+I R
$$

The input electrical power of the thermoelectric is given by

$$
P=\alpha I\left(T_{h}-T_{c}\right)+I^{2} R .
$$

The coefficient of performance of thermoelectric can be obtained by

$$
\mathrm{COP}=\frac{Q_{c}}{P}
$$

3.2. Experiment Setup. In order to quantitatively evaluate the cooling performance of a solar thermoelectric chiller, the following parameters should be considered: the solar cell power, the thermoelectric power consumption, the hot side and cold side temperatures of the thermoelectric system, and the coefficient of performance (COP). Figure 2 illustrates the schematic organization of our experimental system for determining cooling performance of the solar thermoelectric chiller.

All of the experiments used cooling $250 \mathrm{~mL}$ water in water tank, which was connected to the cold side of the thermoelectric system. The thermoelectric chiller was driven by a fixed $9.6 \mathrm{~V}$ direct current source and solar cells, respectively. According to (3), the voltage of thermoelectric is related to the Seebeck coefficient $\alpha$, the temperature difference between hot and cold sides $\left(T_{h}-T_{c}\right)$, the electric current of thermoelectric $I$, and the thermoelectric resistance $R$. The voltage of thermoelectric may change with respect to the changes of the above variables and approach to the fixed direct current. We investigate the cooling capacity of the solar thermoelectric chiller in 180 minutes. We used a power analyzer to measure the power consumption of the thermoelectric system. For data logging, we used a data logger and its associated software to grab the evaluation data. The $T$-type thermocouples were used for continuous measurement of hot side and cold side temperatures, ambient temperature, and water tank temperature. Type $T$ (copper-constantan) thermocouples are suitable for measurements in the -200 to $350^{\circ} \mathrm{C}$ range and have a sensitivity of about $43 \mu \mathrm{V} /{ }^{\circ} \mathrm{C}$. The pyranometer was used for continuous measurement of solar insolation. It is suitable for measurements in the 0 to $2000 \mathrm{~W} / \mathrm{m}^{2}$ range and has a sensitivity of about $0.1 \mathrm{~W} / \mathrm{m}^{2}$.

Our research goal is to investigate solar thermoelectric chiller. We tested the solar thermoelectric chiller by two stages and proved feasibility.

(1) First Stage Experiment. Using DC source to drive the thermoelectric chiller, we measure the voltage, current, consuming power, the cold side and hot side temperatures, and cooling capacity and analyze the COP. We conduct the test experiments by duration of 180 minutes.

(2) Second Stage Experiment. Using the solar cell to drive thermoelectric chiller, we measure voltage, current, consuming power, the cold side and hot side temperatures, and cooling capacity and analyze the COP. We conduct the test experiments by duration of 180 minutes. 


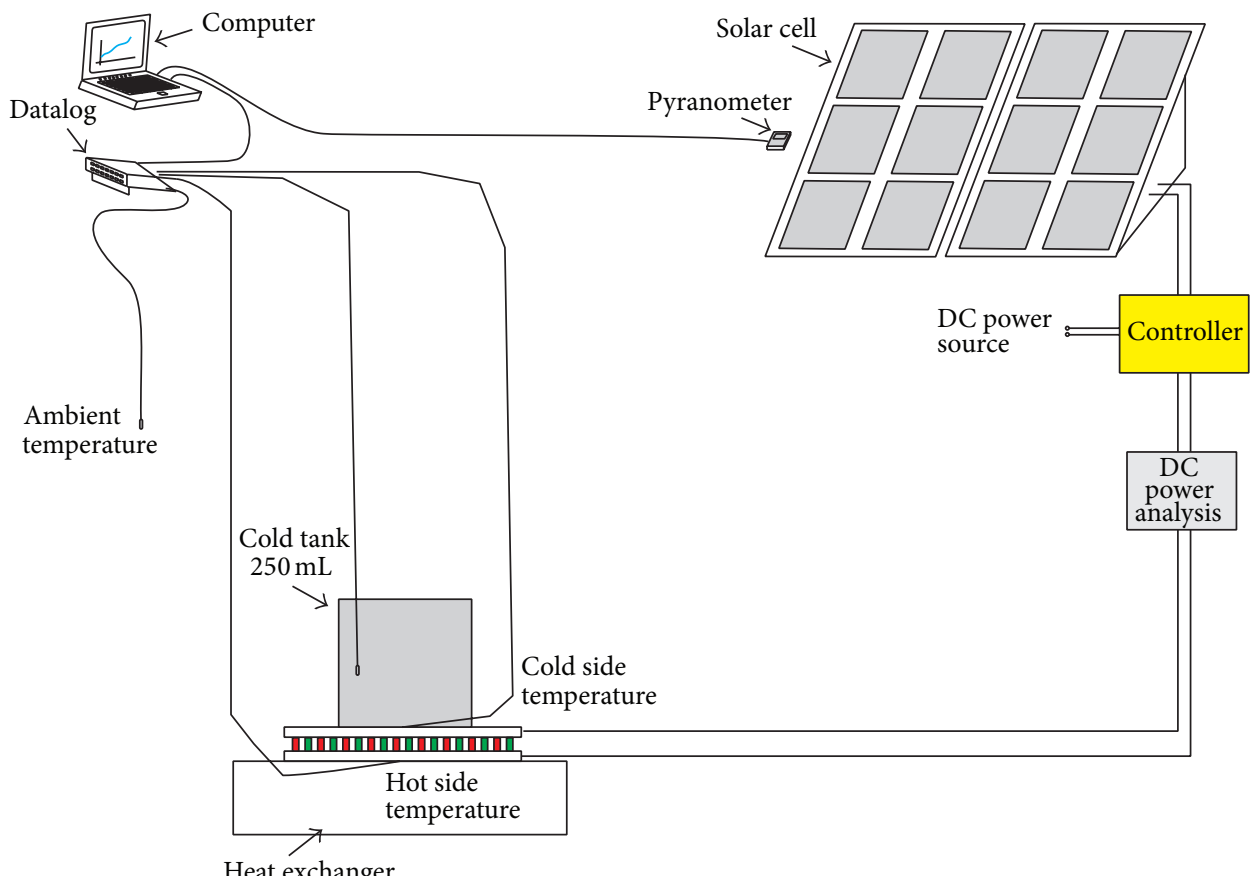

Figure 2: Experimental setup and measurement of solar thermoelectric chiller.

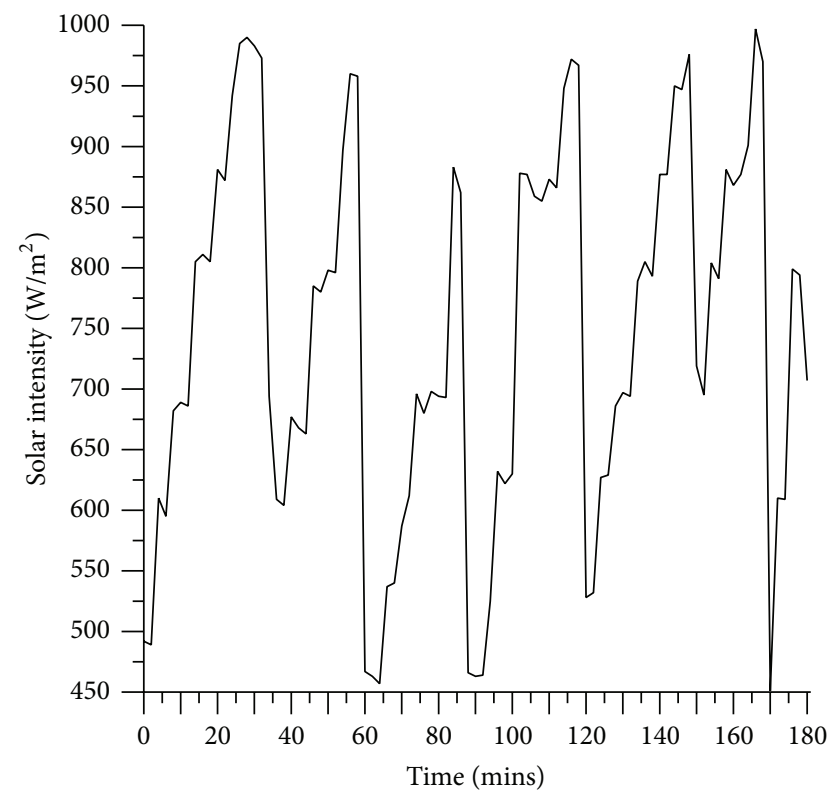

FIgURE 3: Light intensity distribution.

\section{Results and Discussion}

The proposed experiments used twelve halogens to simulate solar light. We adjust the voltage of halogen to change solar intensity. We adjust the light intensity from $450 \mathrm{~W} / \mathrm{m}^{2}$ to $1000 \mathrm{~W} / \mathrm{m}^{2}$ as shown in Figure 3. In Figure 4, the electric voltages of thermoelectric system are stable when the fixed direct current power is supplied to drive the thermoelectric

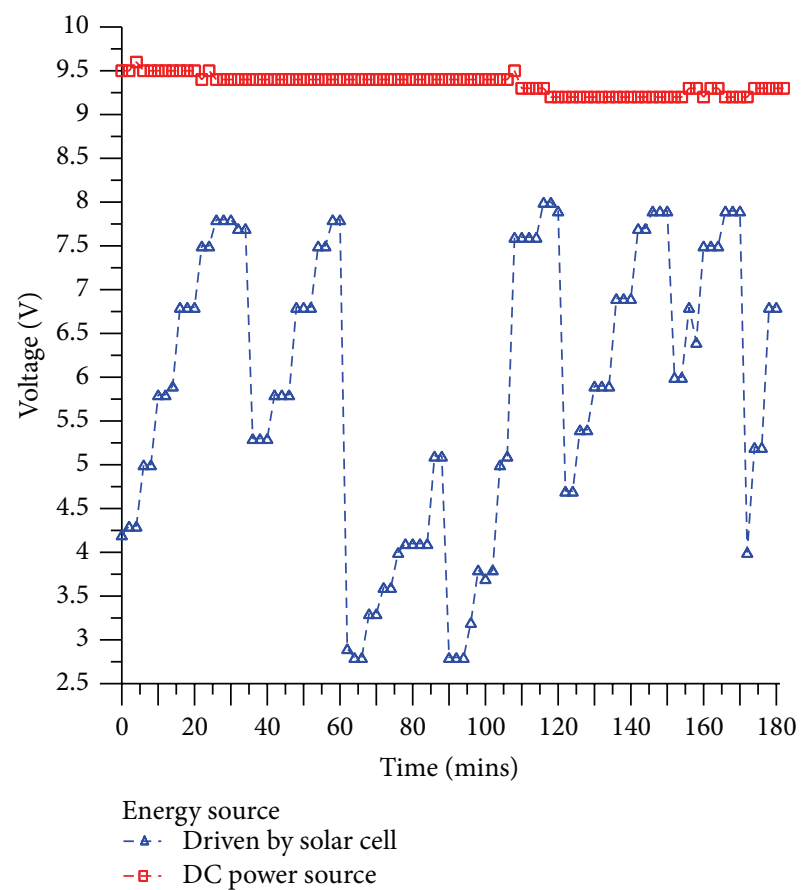

FIGURE 4: The electric voltages of thermoelectric system driven by DC source and solar cells.

system, whereas the voltages of thermoelectric system are varied with respect to the variations of the solar insolation rates. According to Figures 3 and 4, the light intensity and the voltage of thermoelectric are positively correlated. When the lowest light intensity is about $450 \mathrm{~W} / \mathrm{m}^{2}$, the voltage of 


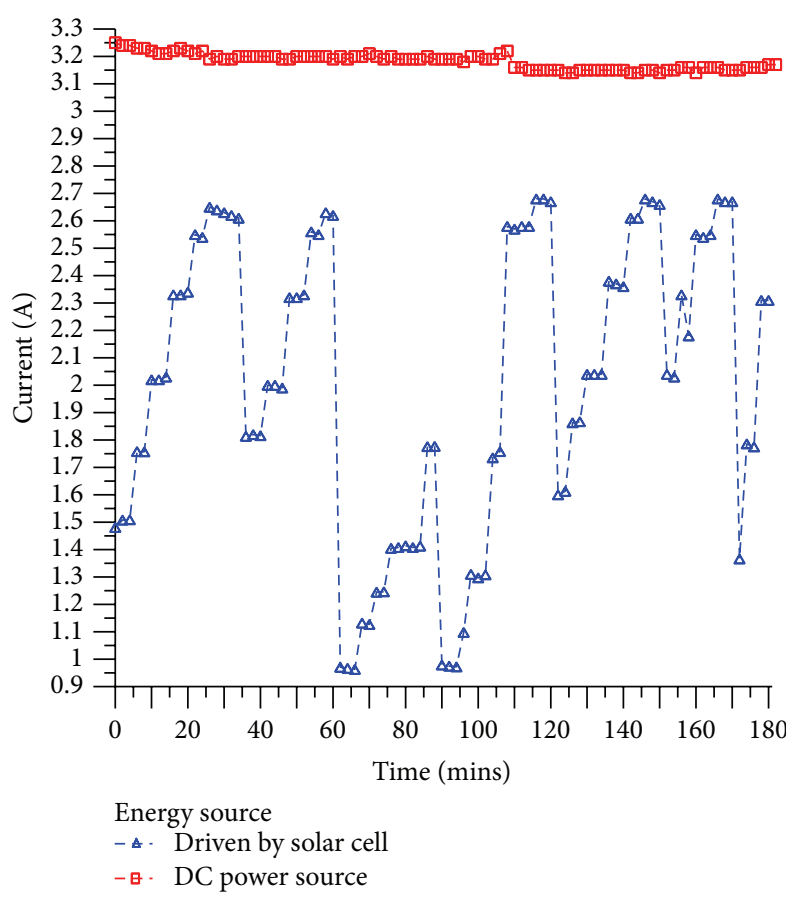

FIGURE 5: The electric currents of thermoelectric system driven by DC source and solar cells.

thermoelectric is about $2.7 \mathrm{~V}$; when the highest light intensity is about $1000 \mathrm{~W} / \mathrm{m}^{2}$, the voltage of thermoelectric is about $8 \mathrm{~V}$. In Figure 5, the electric currents of the thermoelectric system are stable when the fixed direct current power is supplied to drive the thermoelectric system, whereas the currents of the thermoelectric system are varied with respect to the variations of the solar insolation rates. In Figures 6 and 7, we used fixed direct current power to drive the thermoelectric system. The hot side temperature is maintained at about $47^{\circ} \mathrm{C}$, and meanwhile the cold side temperature drops from $0^{\circ} \mathrm{C}$ to $-3.5^{\circ} \mathrm{C}$. When we use the solar cell to drive the thermoelectric system, the hot side temperature and cold side temperature accordingly vary with respect to solar insolation rates. The highest hot side temperature is $36^{\circ} \mathrm{C}$, and the least hot side temperature is $23.5^{\circ} \mathrm{C}$, whereas the highest cold side temperature is $6^{\circ} \mathrm{C}$, and the least hot side temperature is $-3.5^{\circ} \mathrm{C}$.

Figures 8 and 9 show the cold tank temperatures and cooling capacities of the thermoelectric chiller driven by the fixed direct current power and the solar cells. For the thermoelectric chiller driven by the fixed direct current power, the cold tank temperature drops form $20^{\circ} \mathrm{C}$ to $11^{\circ} \mathrm{C}$, and the cooling capacity is maintained at $12 \mathrm{~W}$. For the thermoelectric chiller driven by the solar cell, the cold tank temperature drops rapidly form $18.5^{\circ} \mathrm{C}$ to $14^{\circ} \mathrm{C}$ when the cooling capacity changes from $10.5 \mathrm{~W}$ to $14 \mathrm{~W}$ and the average is cooling capacity $12.2 \mathrm{~W}$. We can see that the cold tank temperature gently drops from $14^{\circ} \mathrm{C}$ to $13^{\circ} \mathrm{C}$ when cooling capacity changes from $5 \mathrm{~W}$ and $17.5 \mathrm{~W}$; the average cooling capacity is $10.6 \mathrm{~W}$ in this range. As shown in Figures 10 and 11, when we use fixed direct current power to drive

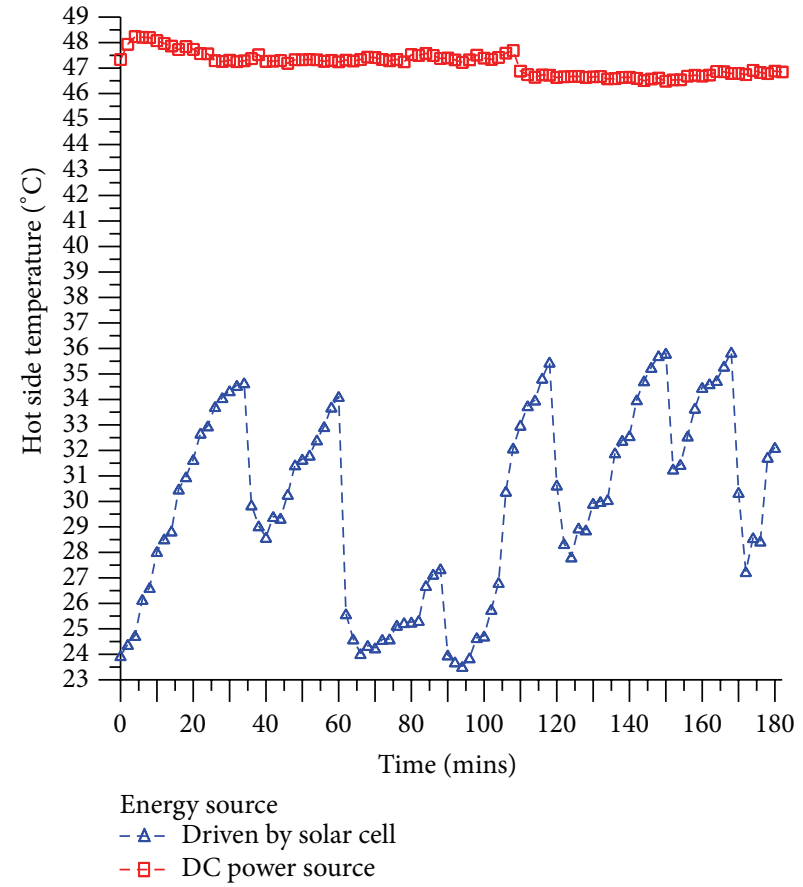

FIGURE 6: The hot side temperatures of the thermoelectric system by DC source and solar cells.

TABLE 2: The average cooling capacity of the semiconductor of the system.

\begin{tabular}{lcccccc}
\hline & \multicolumn{7}{c}{ Average } \\
Result & $S$ & $V$ & $I$ & $P$ & $Q_{c}$ & COP \\
& $\left(\mathrm{W} / \mathrm{m}^{2}\right)$ & $(\mathrm{V})$ & $(\mathrm{A})$ & $(\mathrm{W})$ & $(\mathrm{W})$ & \\
\hline DC power source & & 9.4 & 3.2 & 34.3 & 11.9 & 0.35 \\
Solar cell & 747.9 & 5.9 & 2.0 & 16.7 & 11.2 & 0.74 \\
\hline
\end{tabular}

the thermoelectric chiller, the input electric power of the thermoelectric chiller is maintained at about $35 \mathrm{~W}$ and the $\mathrm{COP}$ value is maintained at about 0.35 . By comparison, when we adopt the solar cell to drive the thermoelectric chiller, the lowest value of the input electric power of the thermoelectric system is $5.5 \mathrm{~W}$, while the highest value is $26 \mathrm{~W}$, and the lowest COP is 0.55 , while the highest COP is 1.05 . We observe that the solar cell driven thermoelectric system can provide significantly better COP and needs lower input electric power consumption for the thermoelectric system. As shown in Table 2, the average cooling capacity of the solar driven system is $11.2 \mathrm{~W}$, which is lower than the one of the system driven by fixed direct current of $11.9 \mathrm{~W}$. By comparison, the average COP of the solar driven system is 0.74 , which is better than the one driven by fixed direct current of 0.35 . This is because the solar driven system is operated on an average of electric current of $2 \mathrm{~A}$, which is a better operating point than that of the fixed direct current driven system. 


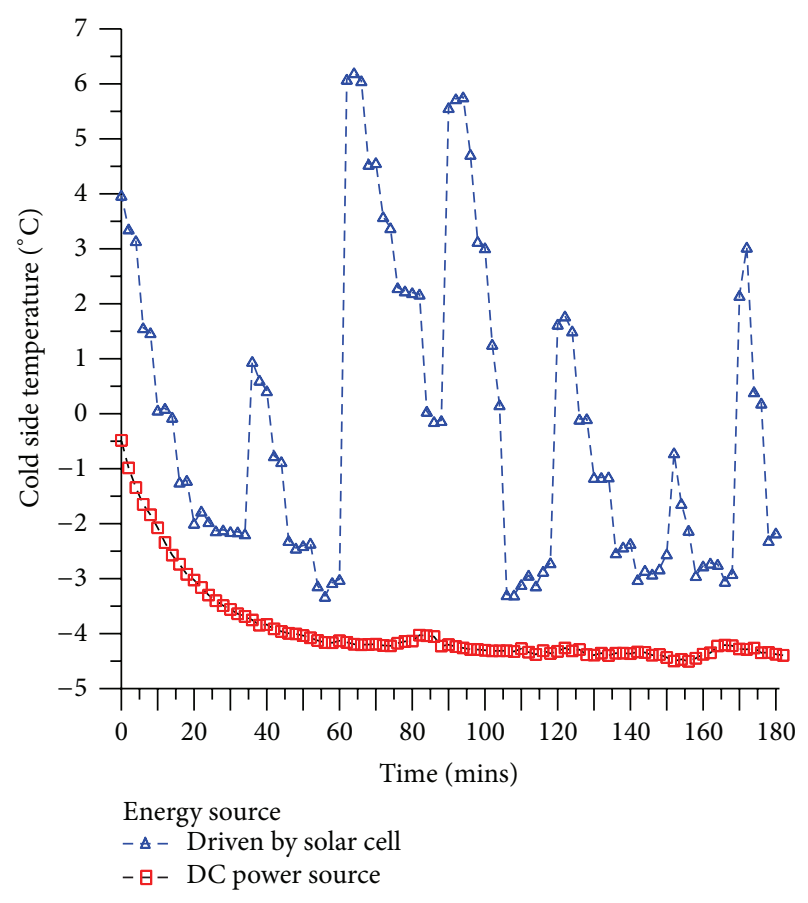

FIGURE 7: The cold side temperatures of the thermoelectric system by DC source and solar cells.

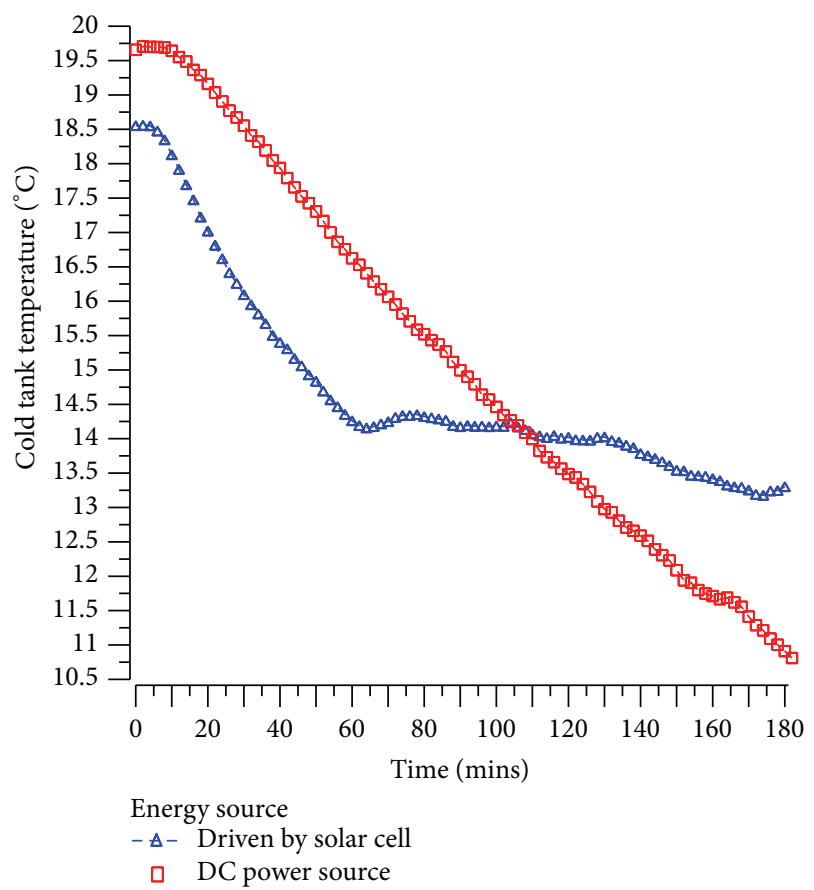

FIgURE 8: The cold tank temperatures of the thermoelectric system by DC source and solar cells.

\section{Conclusions}

This study conducts experimental investigation on a thermoelectric chiller driven by solar cells. This experimental system has been tested, and the test results are presented. By comparing the experimental data of the thermoelectric

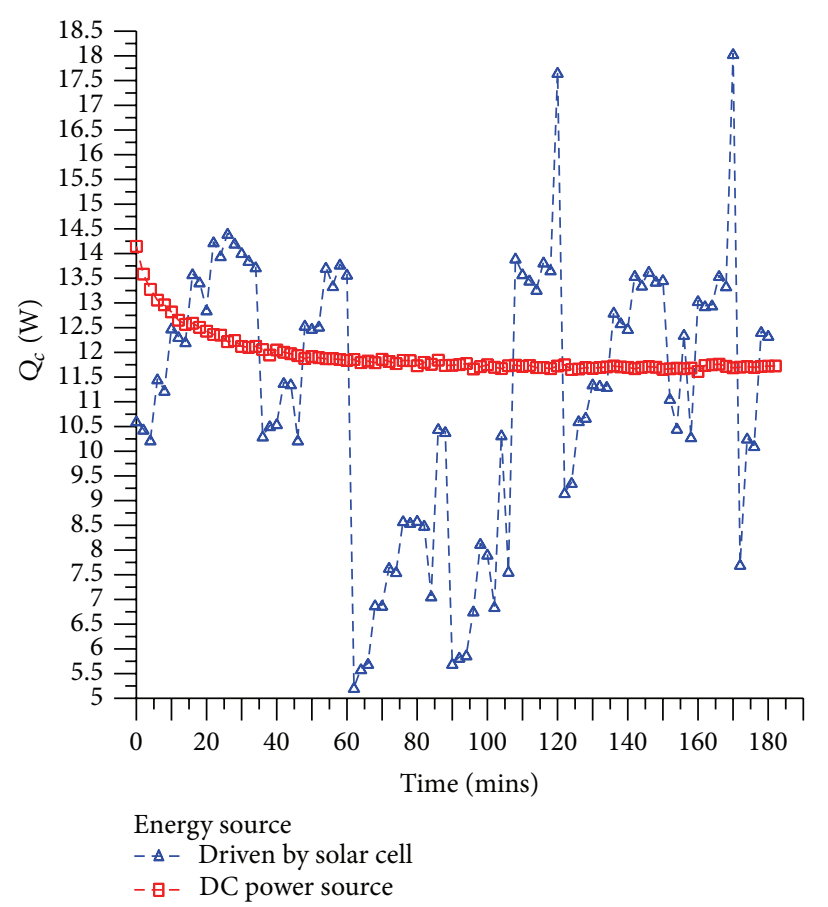

FIGURE 9: Cooling capacity of the thermoelectric system by DC source and solar cells.

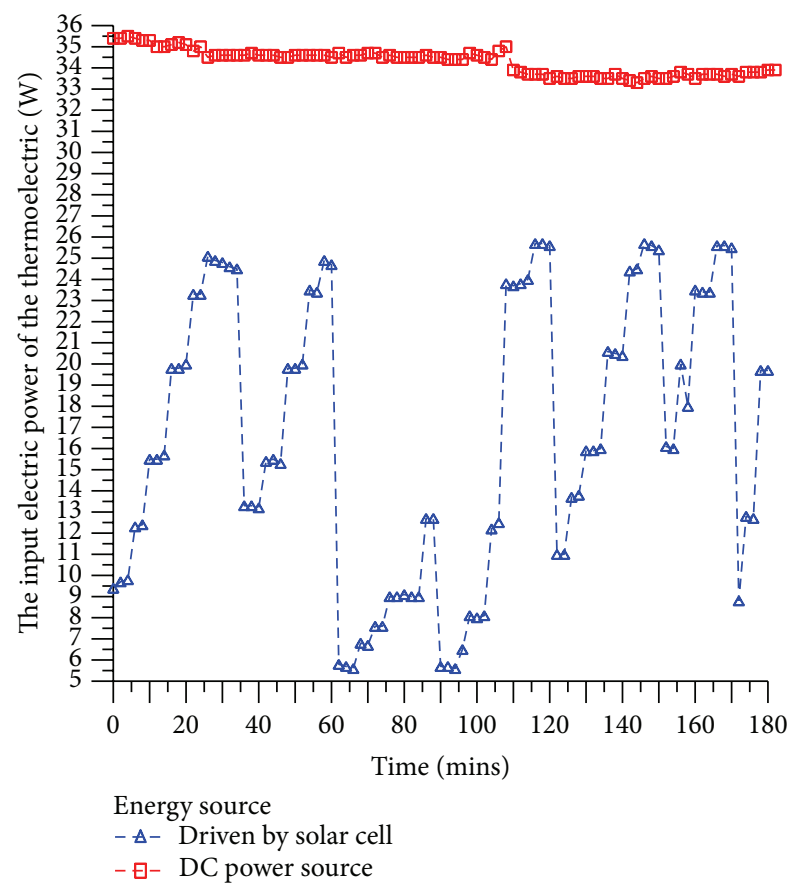

FIgURE 10: The input electric powers of the thermoelectric system by DC source and solar cells.

system driven by direct current source and by the solar cell, we found that the thermoelectric chiller driven by the direct current source provides the cooling capacity of $11.9 \mathrm{~W}$, which is somewhat higher than the one driven by the solar cell $(11.2 \mathrm{~W})$. However, the COP obtained by the solar driven system is 0.74 , which is significantly better than the one 


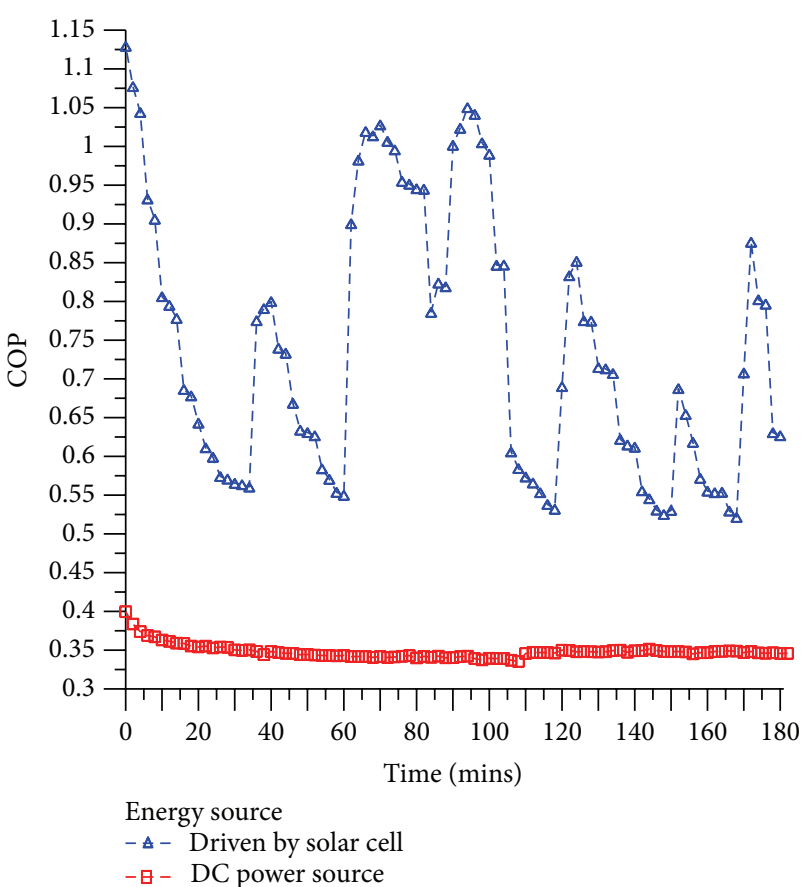

FIGURE 11: COPs of the thermoelectric chiller by DC source and solar cells.

driven by direct current of 0.35 . Although the thermoelectric system driven by fixed direct current can provide stable cooling capacity, the thermoelectric chiller driven by the solar cell can provide significantly better COP, which ranges between 0.55 and 1.05 , with an average of 0.74 , than that driven by the fixed direct current. The experimental results also reveal that if the solar insolation rate can achieve $450 \mathrm{~W} / \mathrm{m}^{2}$ to $1000 \mathrm{~W} / \mathrm{m}^{2}$, the solar thermoelectric chiller can provide feasible and effective performance.

\section{Nomenclature}

A: $\quad$ Area of solar array, $\mathrm{m}^{2}$

I: $\quad$ Electric current, A

K: $\quad$ Thermal conductance, $\mathrm{WK}^{-1}$

$P_{\text {solar }}: \quad$ Output electric power of solar cell, $\mathrm{W}$

$P: \quad$ Input electric power of the thermoelectric chiller, W

$Q_{c}: \quad$ Cooling capacity, W

$R: \quad$ Thermoelectric resistance, $\Omega$

$S$ : Solar insolation,

$T_{H}: \quad$ Temperature of hot side, $\mathrm{K},{ }^{\circ} \mathrm{C}$

$T_{\mathrm{C}}$ : $\quad$ Temperature of cold side, $\mathrm{K},{ }^{\circ} \mathrm{C}$

$T_{w}$ : Temperature of water in cold tank, $\mathrm{K},{ }^{\circ} \mathrm{C}$

$\Delta T_{\max }:$ Maximum temperature difference between hot and cold sides, $\mathrm{K},{ }^{\circ} \mathrm{C}$

$V: \quad$ Electric voltage, $\mathrm{V}$

$Z: \quad$ Figure of merit, $1 / \mathrm{K}$

$\alpha: \quad$ Seebeck coefficient, $\mathrm{V} / \mathrm{K}$

$\eta_{P V}$ : Energy efficiency of solar cells.
Abbreviations

COP: Coefficient of performance

TEC: Thermoelectric cooler

DC: Direct current.

\section{Subscripts}

solar: Solar cell

tec: Thermoelectric cooler

max: Maximum.

\section{Conflict of Interests}

The authors declare that there is no conflict of interests regarding the publication of this paper.

\section{Acknowledgment}

This project is financially sponsored by the National Science Council under Grants NSC-102-2219-E-027-006 and NSC102-2622-E-027-027-CC2.

\section{References}

[1] D. Lalili, A. Mellit, N. Lourci, B. Medjahed, and C. Boubakir, "State feedback control and variable step size MPPT algorithm of three-level grid-connected photovoltaic inverter," Solar Energy, vol. 98, pp. 561-571, 2013.

[2] Z.-J. Chien, H.-P. Cho, C.-S. Jwo, C.-C. Chien, S.-L. Chen, and Y.-L. Chen, "Experimental investigation on an absorption refrigerator driven by solar cells," International Journal of Photoenergy, vol. 2013, Article ID 490124, 6 pages, 2013.

[3] Y. J. Dai, R. Z. Wang, and L. Ni, "Experimental investigation and analysis on a thermoelectric refrigerator driven by solar cells," Solar Energy Materials \& Solar Cells, vol. 77, no. 4, pp. 377-391, 2003.

[4] A. Gaur and G. N. Tiwari, "Performance of photovoltaic modules of different solar cells," Journal of Solar Energy, vol. 2013, Article ID 734581, 13 pages, 2013.

[5] D. Yang and H. Yin, "Energy conversion efficiency of a novel hybrid solar system for photovoltaic, thermoelectric, and heat utilization," IEEE Transactions on Energy Conversion, vol. 26, no. 2, pp. 662-670, 2011.

[6] S. B. Riffat and X. Ma, "Thermoelectrics: a review of present and potential applications," Applied Thermal Engineering, vol. 23, no. 8, pp. 913-935, 2003.

[7] M. H. Elsheikh, D. A. Shnaeah, M. F. M. Sabri et al., "A review on thermoelectric renewable energy: principle parameters that affect their performance," Renewable and Sustainable Energy Reviews, vol. 30, pp. 337-355, 2014.

[8] D. Mitrani, J. Salazar, A. Turó, M. J. García, and J. A. Chávez, "One-dimensional modeling of TE devices considering temperature-dependent parameters using SPICE," Microelectronics Journal, vol. 40, pp. 1398-1405, 2009.

[9] H. Xi, L. Luo, and G. Fraisse, "Development and applications of solar-based thermoelectric technologies," Renewable and Sustainable Energy Reviews, vol. 11, no. 5, pp. 923-936, 2007.

[10] D. Champier, J. P. Bédécarrats, T. Kousksou, M. Rivaletto, F. Strub, and P. Pignolet, "Study of a TE (thermoelectric) generator 
incorporated in a multifunction wood stove," Energy, vol. 36, no. 3, pp. 1518-1526, 2011.

[11] F. Meng, L. Chen, F. Sun, and B. Yang, "Thermoelectric power generation driven by blast furnace slag flushing water," Energy, vol. 66, pp. 965-972, 2014.

[12] P. M. Attia, M. R. Lewis, C. C. Bomberger, and A. K. Prasad, "Experiment studies of thermoelectric power generation in dynamic temperature environments," Energy, vol. 60, pp. 453456, 2013.

[13] A. Rezania, L. A. Rosendahl, and S. J. Andreasen, "Experimental investigation of thermoelectric power generation versus coolant pumping power in a microchannel heat sink," International Communications in Heat and Mass Transfer, vol. 39, no. 8, pp. 1054-1058, 2012.

[14] E. A. Chávez Urbiola and Y. Vorobiev, "Investigation of solar hybrid electric/thermal system with radiation concentrator and thermoelectric generator," International Journal of Photoenergy, vol. 2013, Article ID 704087, 7 pages, 2013.

[15] D. Zhao and G. Tan, "A review of thermoelectric cooling: materials, modeling and applications," Applied Thermal Engineering, vol. 66, pp. 15-24, 2014.

[16] W. He, J. Zhou, J. Hou, C. Chen, and J. Ji, “Theoretical and experimental investigation on a thermoelectric cooling and heating system driven by solar," Applied Energy, vol. 107, pp. 8997, 2013.

[17] Y. Zhou and J. Yu, "Design optimization of thermoelectric cooling systems for applications in electronic devices," International Journal of Refrigeration, vol. 35, no. 4, pp. 1139-1144, 2012.

[18] S. A. Abdul-Wahab, A. Elkamel, A. M. Al-Damkhi et al., "Design and experimental investigation of portable solar thermoelectric refrigerator," Renewable Energy, vol. 34, no. 1, pp. 30-34, 2009.

[19] Y.-W. Chang, C.-C. Chang, M.-T. Ke, and S.-L. Chen, "Thermoelectric air-cooling module for electronic devices," Applied Thermal Engineering, vol. 29, no. 13, pp. 2731-2737, 2009. 

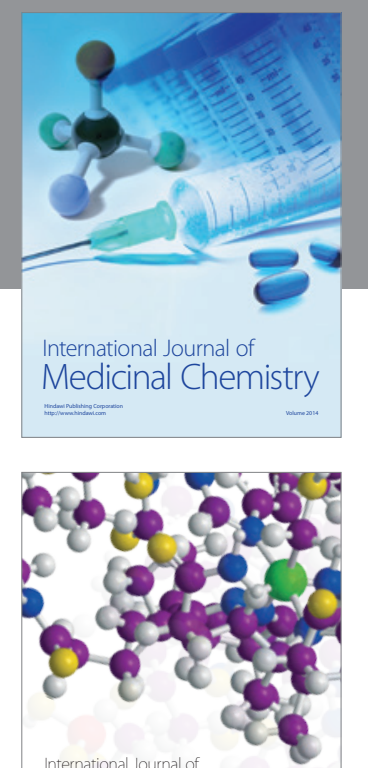

\section{Carbohydrate} Chemistry

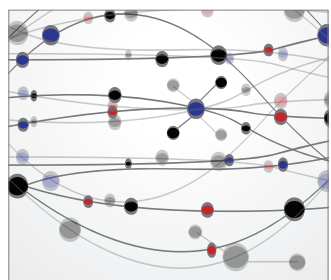

The Scientific World Journal
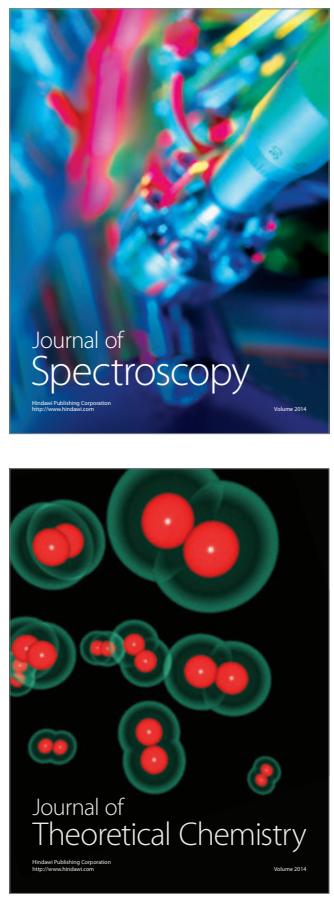
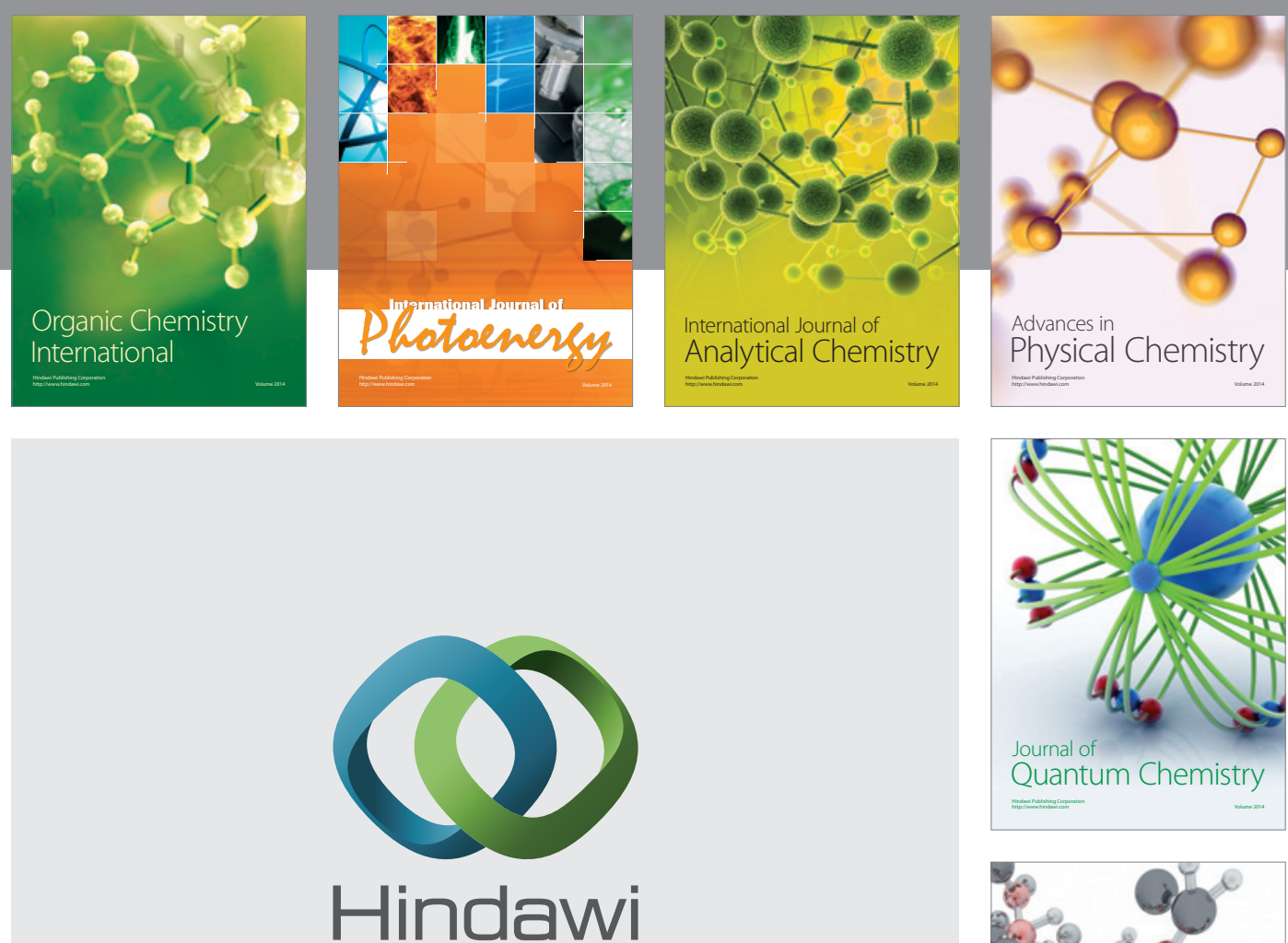

Submit your manuscripts at

http://www.hindawi.com

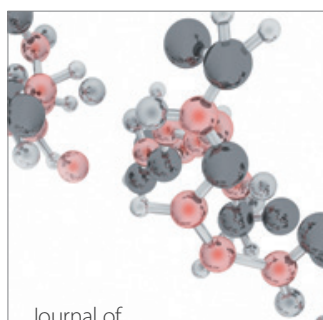

Analytical Methods

in Chemistry

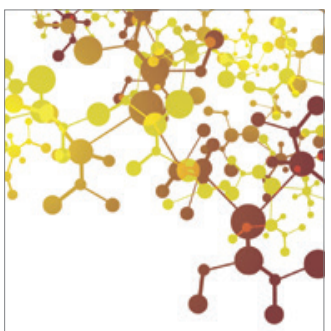

Journal of

Applied Chemistry

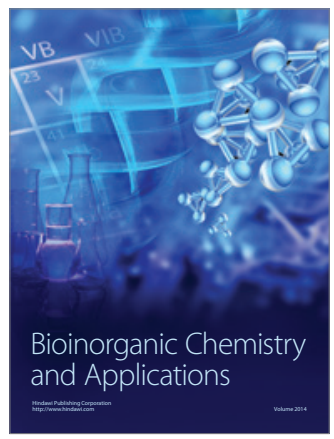

Inorganic Chemistry
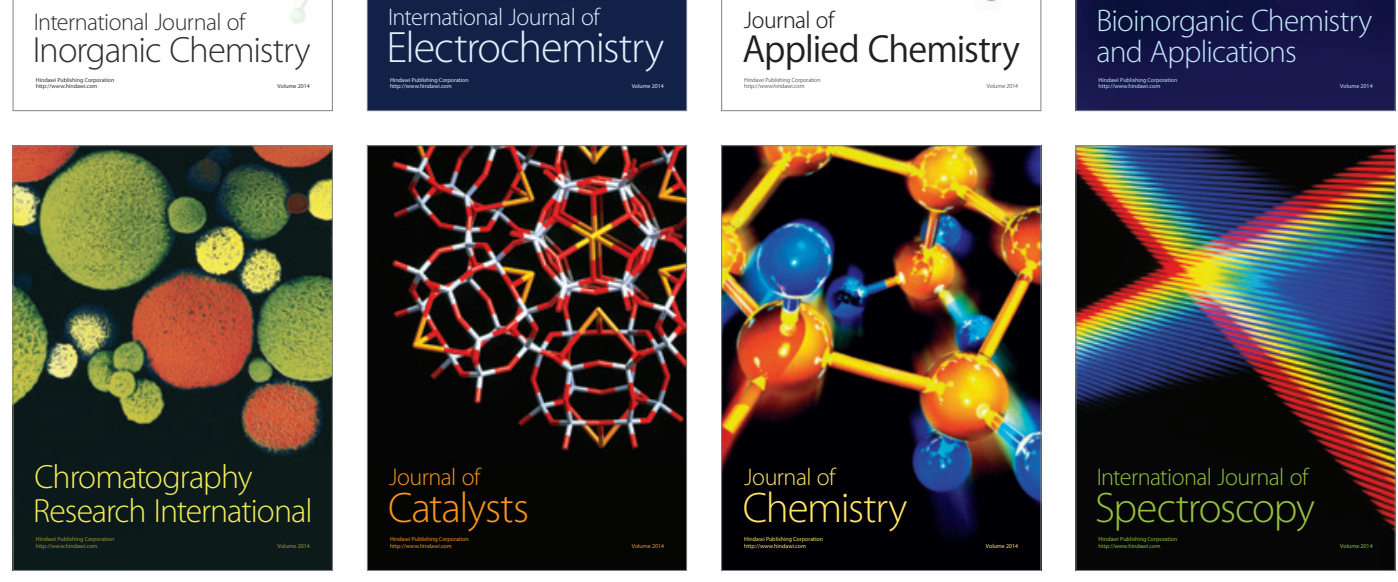